\title{
AHMAD SANOESI (1888-1950), penggerak Organisasi al-ITtIHadijatoel ISLAMIJJAH (AII)
}

\author{
AHMAD SANOESI (1888-1950): \\ MOTIVATOR OF AL-ITTIHADIJATOEL ISLAMIJIAH (AII)
}

\author{
Oleh Wawan Hernawan \\ Fakultas Ushuluddin UIN Sunan Gunung Djati Bandung \\ Jl. A.H. Nasution No. 105 Cibiru-Kota Bandung 40614 \\ E-mail: wanha99@yahoo.co.id
}

\begin{abstract}
Abstrak
Terdapat perbedaan sikap politik yang dilakukan Sanoesi terhadap pemerintah Hindia Belanda dan pemerintah pendudukan Jepang. Ia memilih konflik dengan pemerintah Hindia Belanda, sebaliknya kompromi dengan pemerintah pendudukan Jepang. Ia begitu antipati terhadap pemerintah Hindia Belanda, sebaliknya simpati terhadap pemerintah pendudukan Jepang. Penelitian ini bermaksud merekonstruksi pergerakan yang dilakukan Sanoesi semasa hidupnya (1888-1950). Ini menjadi penting, di tengah kecenderungan masyarakat yang selalu mengidolakan tokoh global, kita dituntut bersikap arif terhadap tokoh lokal yang mempunyai andil besar dalam upayanya menemukan sejarah bangsa. Dengan menggunakan metode penelitian sejarah, ditemukan bahwa pergerakan Sanoesi telah dirintis sejak masa muda hingga wafat menjemputnya. Sanoesi telah banyak memberikan kontribusi bagi tumbuhnya pola-pola pergerakan yang kemudian diikuti oleh generasi sesudahnya. Sanoesi pun berhasil memberikan solusi bagi masyarakat pribumi terutama dalam bidang pendidikan dan dakwah. Kehadiran organisasi Al-Ittihadijatoel Islamijjah (AII) di Indonesia adalah fakta. Fakta lainnya, mewakili organisasi yang dipimpinnya ia terpilih menjadi Wakil Residen Bogor, anggota Cuo Sangi In, anggota Dokuritu Zyunbi Tyoosakai (BPUPKI), dan anggota Komite Nasional Indonesia Pusat (KNIP).
\end{abstract}

Kata kunci: Ajengan, Interneer, AII, POII.

\begin{abstract}
Sanoesi showed different attitude towards the government of Dutch Indies and the government of the Japanese occupation. He chose conflict with the first; instead compromise with the second. He was so antipathetic to the Dutch, otherwise sympathetic to the Japanese. This study intends to reconstruct Sanoesi movements during his lifetime (1888-1950). This would be important in the midst of tendency to idolize global leaders, and it would be wise to appreciate local leaders who have contributed in the development of the history of our nation. By conducting history methods, it was found that Sanoesi began his movement in his youth and continued until his death. Sanoesi had contributed
\end{abstract}


greatly to the growth of patterns for the movement which were followed by later generations. He provided solutions to indigenous people especially in education and dakwah (giving enlightment). The presence of Al-Ittihadijatoel Islamijjah organization (AII) in Indonesia is a proof for his contribution, and as representative for the organization he was elected Vice-Resident of Bogor, became member of Cuo Sangi-in, of Dokuritu Zyunbi Tyoosakai (BPUPKI), and of the Central Indonesian National Committee (KNIP).

Keywords: ajengan, interneer, AII, POII

\section{A. PENDAHULUAN}

Informasi pertama mengenai Sanoesi, diperoleh dari Pendaftaran Orang Indonesia Jang Terkemoeka Jang Ada di Djawa kepada Gunseikanbu Tjabang I, Pegangsaan Timoer 36 Djakarta, pada 2602/1942. Sanoesi menuliskan namanya, Ah. Sanoesi. Sumber itu memberikan informasi, Sanoesi dilahirkan pada 18 September 1888 di desa Tjantajan onderdistrik Tjikembar, Sukaboemi. Sanoesi tidak sekolah secara formal di lembaga pendidikan formal gubernemen, tetapi masuk ke beberapa pesantren di Jawa dan melanjutkan studinya ke Mekkah. Beberapa tahun setelah kepulangannya dari Mekkah ia mendirikan pesantren di Babakan Sirna, Kampung Genteng (Mawardi, 2011: 98). Beberapa tahun setelah mendirikan pesantren Genteng, tanpa alasan yang jelas dan putusan pengadilan Sanoesi ditangkap dan diinterneer (diasingkan) ke Batavia Centrum (Sipahoetar, 1946: 74-77). Pada saat di pengasingan itulah, Sanoesi didaulat oleh para murid dan pengikutnya untuk menjadi voorzitter hoofdbestuur Al-Ittihadijatoel Islamijjah (AII) (Iskandar, 1991: 255). Diduga, karena penangkapan dan pengasingan itulah Sanoesi dan anggota AII mengambil sikap konflik dan antipati terhadap pemerintah Hindia Belanda.

Sikap antipati Sanoesi dan anggota AII terhadap pemerintah Hindia Belanda berbanding terbalik dengan simpati (sikap politik kompromi) mereka terhadap pemerintah pendudukan Jepang. Pada masa pemerintah pendudukan Jepang Sanoesi dan AII lebih banyak memperoleh kemudahan. Misalnya, Sanoesi ditawari untuk menjadi anggota Dewan Penasihat Daerah (Shu Sangi Kai) Keresidenan Bogor. Pada tahun yang sama Sjamsoeddin, sebagai anggota AII juga ditawari menjadi ketua Gerakan Tiga A (Iskandar, 1991: 276; Sulasman, 2007: 76). Selanjutnya, seiring pergantian nama AII menjadi POII, Sanoesi diserahi jabatan sebagai Wakil Residen Bogor, dan ketika dibentuk Dokuritu Zyunbi Tyoosakai (BPUPKI), Sanoesi dan Sjamsoeddin mewakili organisasi POII terpilih menjadi anggota badan tersebut. 
Bertolak dari uraian di atas, muncul beberapa persoalan yang kemudian menjadi pertanyaan penelitian. Pertama, bagaimana kehidupan dan kiprah Sanoesi sebelum berdirinya Al-Ittihadijatoel Islamijjah (AII)? Kedua, bagaimana kiprah Sanoesi sebagai Ketua dan penggerak Al-Ittihadijatoel Islamijjah (AII)? Ketiga, mengapa Sanoesi dan anggota AII antipati terhadap pemerintah Hindia Belanda, tetapi bersimpati terhadap pemerintah pendudukan Jepang? Keempat, bagaimana peranan Sanoesi pada awal kemerdekaan Indonesia?

Penelitian ini bermaksud melakukan rekonstruksi terhadap masa muda Sanoesi dan pendidikannya, kiprah Sanoesi sebelum berdirinya AII, meliputi pergerakan Sanoesi ketika menjadi Ajengan dan kiprah Sanoesi selama di pengasingan, kiprah Sanoesi sebagai ketua dan penggerak AII, dan peranan Sanoesi pada awal kemerdekaan. Melalui penelitian ini diharapkan dapat memperjelas Kiprah Sanoesi sebagai penggerak AII, sesuai topik penelitian.

Sanoesi (1888-1950) menarik untuk diteliti, karena beberapa alasan. Pertama, 1888 adalah tahun kelahiran Sanoesi. Padanya bisa dilekatkan kehidupan keluarga dan pendidikannya. Kedua, 1950 dijadikan sebagai lingkup akhir penelitian, karena pada tahun itu Sanoesi wafat. Ketiga, dari tahun 1888-1950 Sanoesi telah menunjukkan dedikasinya di masyarakat sebagai tokoh penggerak AII yang dirangkum dalam pergerakannya selama di pengasingan, Wakil Residen Bogor, anggota Cuo Sangi In, anggota Dokuritu Zyunbi Tyoosakai (BPUPKI), dan anggota Komite Nasional Indonesia Pusat (KNIP). Pada rentang 1888-1950 Sanoesi mampu memberikan solusi tersendiri bagi persoalan-persoalan yang dihadapi kaum Muslim pribumi. Adapun aspek spasial dalam penelitian ini meliputi wilayah Batavia Centrum dan Sukabumi sebagai basis organisasi AII.

Beberapa aspek tentang latar belakang dan tokoh pendiri AII, di antaranya ditemukan pada buku, Siapa? Loekisan para Pemimpin, disusun Sipahoetar dan diterbitkan pada 1946 oleh Pertjetakan Pemerintah Soekaboemi. Penulis buku itu mendapatkan informasi langsung melalui wawancara dengan Sanoesi di Gunung Puyuh. Buku setebal 76 halaman itu membahas tempat kelahiran Sanoesi, pendidikan, watak dan sifat, pengalaman, dan pengetahuan agama Sanoesi. Sekalipun tipis dari sisi jumlah halaman, buku itu cukup memberikan informasi mengenai gerak perjuangan Sanoesi dalam AII.

Buku selanjutnya ditulis oleh Lubis et al., Sejarah Calon Pahlawan Nasional K.H. Ahmad Sanoesi Berdasarkan Buku-buku dan Kesaksian Dalam rangka Pengusulannya 
sebagai Pahlawan Nasional. Sesuai dengan judulnya, buku itu memberikan informasi tentang kehidupan Sanoesi dan perjuangannya membina organisasi AII hingga 1950.

Sumber lainnya diperoleh dari disertasi berjudul, Ortodoksi Tafsir: Respons Ulama terhadap tafsir Tamsjijjatoel-Moeslimien Karya K.H. Ahmad Sanoesi, ditulis Darmawan pada 2009. Dalam disertasi itu dikemukakan riwayat aktivitas Ahmad Sanoesi, karya tulis, dan sejarah pemikirannya. Dari hasil kajian pustaka, diketahui bahwa sumbersumber literer terkait dengan Sanoesi dan pergerakannya dapat dikatakan cukup tersedia. Hingga di sini, meskipun secara umum kajian pada buku dan penelitian terdahulu membahas persoalan yang sama, yaitu Sanoesi dan pergerakannya, peneliti akan menambahkan kajian itu dengan menyertakan sejumlah sumber lainnya, termasuk sumber kolonial.

Metode yang digunakan dalam penelitian ini adalah metode sejarah yang meliputi empat tahap, yaitu heuristik, kritik, interpretasi, dan historiografi (Garaghan, 1946: 103426; Gottschalk, 1986: 32; Renier, 1997: 118; Lubis, 2008: 17-60). Terutama dalam heuristik, penulis melakukan kajian ke berbagai lembaga kearsipan, perpustakaan, dan museum, seperti: Arsip Nasional Republik Indonesia, Perpustakaan Nasional Republik Indonesia, Bibliotheek Koninklijk Institut voor Taal Land en Volkenkunde (KITLV, Leiden), Universiteit Bibliotheek (UB, Leiden), dan Perpustakaan Perguruan Syamsul Uluum Sukabumi.

\section{B. HASIL DAN BAHASAN}

\section{Masa Muda Sanoesi dan Pendidikannya (1888-1915)}

Sebagaimana disebutkan di atas, Sanoesi dilahirkan pada 18 September $1888 .^{1}$ Mengenai tempat lahirnya, Sipahoetar (1946: 72) menyebutkan, di desa Tjantajan ${ }^{2}$

\footnotetext{
${ }^{1}$ Terkait dengan kelahiran Sanoesi baik dalam penanggalan Hijriah maupun Masehi terdapat beberapa pendapat, di ataranya: berdasarkan keterangan yang ditulis pada nisan makamnya, Sanoesi lahir pada 3 Muharam 1306. Tanggal itu berbeda dengan yang ia tulis pada Pendaftaran Orang Indonesia jang Terkemoeka jang Ada di Djawa sebagaimana disebutkan di atas (RA. III-6. No. S 283. ANRI). Para penulis seperti: Iskandar (1993: 2), Sulasman (2007: 19), dan Mawardi (1985: 41), menulis kelahiran Ahmad Sanoesi 18 September 1889. Sementara Falah (2009: 9), menyebutkan keduanya, yaitu 1888 dan 1889. Alasan yang dikemukakan Falah untuk 1888 berdasar pada ANRI, RA. III-6. No. S 283 dan Sipahoetar (1946: 72) dan untuk 1889 berdasar pada pemeriksaan Sanoesi oleh Karnabrata seorang Wedana Patih Afdeeling Soekaboemi pada 7 Oktober 1919. Ketika itu Sanoesi mengaku berusia 30 tahun (Proces Verbaal Hadji Ahmad Sanoesi tanggal 7 Oktober 1919 dalam Koleksi R.A. Kern No. 278. KITLV).

${ }^{2}$ Tjantajan atau Cantayan pada saat Sanoesi dilahirkan merupakan kampung terpencil yang terletak di balik dua bukit antara gunung Sunda dan gunung Walat. Menurut Mawardi (1985: 5), hingga 1970 setiap orang yang akan menuju kampung Cantayan harus melewati jembatan sederhana sungai Cimahi (sekarang masuk wilayah kecamatan Cisaat). Dari jembatan itu, kemudian menyusuri jalanan terjal batu kapur ke arah selatan kurang lebih 4 (empat) kilo meter.
} 
onderdistrik Tjikembar, distrik Tjibadak, kabupaten Sukaboemi. Sanoesi kecil dipanggil oleh keluarga dan masyarakat di kampungnya "Uci" (Wanta, 1991:2). Ayahnya bernama Abdurrohim ibn Yasin dan ibunya Empo. Menurut sumber tradisi, Sanoesi diduga, masih memiliki garis keturunan dari Anggadipa (Tumenggung Wiradadaha III, dikenal Dalem Sawidak bupati Sukapura ke III) melalui jalur ayahnya (Mawardi: 1985: 30).

Sebagai anak kalangan somah, Sanoesi tidak sekolah di lembaga pendidikan formal. Setelah usianya cukup yang menurut Sipahoetar (1946: 72), setelah berusia 15 tahun ia belajar agama Islam ke beberapa pesantren di Sukabumi, Cianjur, Garut, hingga Tasikmalaya. Atas anjuran ayahnya, mula-mula Sanoesi masuk Pesantren Selajambe Cisaat dibawah bimbingan Mohammad Anwar. Sulasman (2007: 23) menyebutkan, masa studi Sanoesi di pesantren ini berlangsung selama delapan bulan. Sanoesi selanjutnya pindah ke Pesantren Sukamantri Cisaat. Di pesantren ini ia belajar kepada Mohammad Siddik. Di pesantren ini pun Sanoesi tidak kerasan, sehingga masa studinya hanya berlangsung dua bulan. Setelah itu, ayahnya menganjurkan untuk masuk Pesantren Sukaraja. Di sini, Sanoesi belajar kepada Djenal Arif dan Hafidz selama enam bulan (Iskandar, 1993: 3). Selanjutnya Sanoesi masuk Pesantren Cilaku di Cianjur selama dua belas bulan. Setelah itu, masuk Pesantren Ciajag, masih di Cianjur selama lima bulan. Dari beberapa sumber yang ada, nama guru-guru Sanoesi di kedua pesantren ini tidak disebutkan. Pesantren yang pernah menjadi tempat belajar Sanoesi selanjutnya adalah Pesantren Gudang di Tasikmalaya. Di pesantren ini, Sanoesi belajar kepada Sudja'i selama dua belas bulan. Setelah itu melanjutkan ke Pesantren Gentur Cianjur dibawah bimbingan Ahmad Sjatibi, selama tiga bulan. Tempat mesantren Sanoesi selanjutnya adalah Keresek dan Bunikasih, keduanya di Garut. Masa studi Sanoesi di Pesantren Keresek selama tujuh bulan dan di Pesantren Buniasih selama tiga bulan. Dari beberapa sumber yang berhasil diidentifikasi, di kedua pesantren terakhir tidak disebutkan guru Sanoesi. Setelah itu, Sanoesi kembali ke Pesantren Babakan Selaawi Sukabumi. Di pesantren ini Sanoesi belajar kepada Affandi (Surat Residen Priangan tanggal 15 Desember 1927 No. 50/E, salinan dalam Mailrapporten Geheim No. 679 X/28. ARA; Sipahoetar, 1946: 72).

Setelah melewati rel kereta api, kemudian mendaki bukit yang menjadi batas kecamatan. Setelah itu perjalanan dilanjutkan dengan menuruni bukit hingga memasuki wilayah kecamatan Cikembar. Kondisi jalanan yang naik turun tersebut, menurut Sulasman (2007: 19), masyarakat setempat menyebutnya "Tanjakan Dongeng" atau "Tanjakan Cicohag". Namun demikian, lanjut Sulasman, sekarang jalan tersebut sudah diaspal dan dapat dilalui kendaraan roda empat (Sulasman, 2007: 19). 
Berdasarkan penuturannya kepada Iskandar (1993: 4), dari sejumlah pesantren yang dijadikan tempat belajar Sanoesi, yang paling berkesan baginya adalah Pesantren Gentur, Cianjur. Ketika sedang belajar Ilmu Mantiq ia berbeda pendapat dan berbantahan dengan Sjatibi, gurunya. Bagi kalangan santri waktu itu, berbantahan dengan guru (kyai) merupakan perbuatan tabu dan tidak sopan. Oleh karena itu, Sanoesi dianggap telah melanggar norma pesantren (Sulasman, 2007: 24).

Pada saat menjadi santri di Pesantren Babakan Selaawi, Sanoesi bertemu dengan Djoewariyah putri kyai pesantren tersebut. Mereka kemudian menikah. Selang beberapa bulan setelah pernikahannya, Sanoesi dan Djoewarijah menunaikan ibadah haji. Setelah musim haji selesai ia bersama istrinya bermukim di Mekkah untuk melanjutkan pendidikan agamanya (Sulasman, 2007: 24). Kuat dugaan, dalam tradisi masyarakat saat itu seseorang dapat dipandang "matang" ilmu agamanya bukan hanya telah menyelesaikan studi di beberapa pesantren di tanah air, tetapi juga berhasil melanjutkan studinya ke Mekkah.

Iskandar (1993: 3) menyebutkan, selama masa studinya di Mekkah Sanoesi berguru kepada 'Ali al-Maliki, 'Ali al-Thajjibi, Shaleh Bafadhil, Sa'id Djawani, Abdullah Djamawi, Moehamamad Djoenaidi, dan Moekhtar. Di antara guru-guru Sanoesi itu, yaitu Shaleh Bafadhil adalah seorang mufti Mekkah dan Moehammad Djoenaidi berasal dari Garut, Jawa Barat. Semua guru Sanoesi bermadzhab Syafi'i. Menurut Mawardi (1985: 45), karena kedekatan Sanoesi dengan Shaleh Bafadhil dan sebagai pengakuan atas keluasan ilmu agamanya, ia pernah mendapat kehormatan untuk menjadi imam shalat di Masjidil Haram. Pada waktu itu setiap jamaah haji yang berasal dari Sukabumi sekembalinya ke tanah air selalu membawa cerita mengenai Sanoesi yang masih muda menjadi imam shalat di Masjidil Haram.

Masih dalam masa studinya di Mekkah, pada 1913 Sanoesi bertemu dengan Abdoel Moeloek. Pada pertemuan itu Moeloek memperlihatkan statuten (Anggaran Dasar) organisasi keagamaan di Indonesia Sjarekat Islam (SI). Ketika itu, Moeloek mengajak Sanoesi untuk bergabung. Pada saat itu Sanoesi langsung tertarik, karena SI dipandang memiliki tujuan yang sesuai dengan cita-cita dan harapannya. Hanya saja, proses penerimaan Sanoesi sebagai anggota SI berbeda dengan lainnya. Masuknya Sanoesi tanpa melalui bai'at (sumpah). Hal tersebut, diduga, karena Abdoel Moeloek tidak memiliki kewenangan untuk membai'at. Sejak pertemuan itu, Sanoesi terdaftar sebagai anggota SI (Proces Verbaal Hadji Ahmad Sanoesi tanggal 7 Oktober 1919 dalam koleksi R.A. Kern No. 278. KITLV). Sanoesi pulang ke Sukabumi pada 1915. Sulasman 
(2007: 25) menyebutkan, Sanoesi membawa sejumlah kitab kuning yang pada waktu itu masih jarang dimiliki para kyai di Sukabumi dan sekitarnya.

\section{Kiprah Sanoesi sebelum Berdirinya AlI (1915-1931) \\ 2.1 Sanoesi Menjadi Ajengan}

Sesampainya di Cantayan pada 1915, Sanoesi mendapat tugas mengajar di pesantren ayahnya. Gaya mengajar Sanoesi berbeda dengan para guru lainnya, termasuk dengan ayahnya. Diduga, Sanoesi mulai mengganti metode halaqah dengan metode bandungan atau balagan yang dilanjutkan dengan tanya jawab. Sanoesi mengajar dengan bahasa sederhana. Hal yang sama ia lakukan dalam ceramah-ceramah pengajiannya. Perubahan metode pengajaran agama yang dilakukan Sanoesi berdampak positif. Melalui metode yang dikembangkannya materi pelajaran yang disampaikan dapat diterima lebih mudah oleh para santri dan jama'ahnya. Dalam waktu singkat Sanoesi telah digelari ajengan $^{3}$ oleh masyarakat. Terkait dengan gelarnya itu, sumber-sumber kolonial menyebut Sanoesi sebagai Ajengan Cantayan atau Kyai Cantayan (Proces Verbaal Hadji Ahmad Sanoesi tanggal 7 Oktober 1919 dalam Koleksi R.A. Kern No. 278. KITLV; Laporan Rahasia Mantri Polisi Sukabumi tanggal 20 Agustus 1935 dalam Mailrapporten Geheim No. 953 geh/37. ARA).

Untuk kemandirian dakwahnya, Sanoesi disarankan ayahnya untuk membuka pesantren di kampung Genteng, Distrik Cibadak, Afdeeling Sukabumi. Di Pesantren Genteng, Sanoesi mula-mula mendirikan mesjid. Setelah itu mendirikan bangunanbangunan lain mengelilingi mesjid. ${ }^{4}$ Pada pembukaan pesantren Genteng, santri Sanoesi tidak kurang dari 170 orang. Dengan berdirinya pesantren Genteng, masyarakat tidak hanya memanggil Sanoesi dengan Ajengan Cantayan, tetapi juga Ajengan Genteng (Iskandar, 1993: 6).

Di tengah aktivitas dakwahnya Sanoesi mulai menunjukkan keberaniannya untuk memberlakukan syari'at Islam di Sukabumi. Ia meyakini pintu ijtihad masih terbuka.

${ }^{3}$ Di Jawa Barat, seperti: Bogor, Sukabumi, Cianjur dan beberapa daerah di wilayah Priangan terdapat sebutan lain untuk 'ulama atau elite agama, yaitu Ajengan. Orang yang mendapat gelar ajengan umumnya para pimpinan pondok pesantren yang cukup kharismatik di daerahnya. Hal yang lebih menarik, gelar ajengan juga suka dirangkaikan dengan nama daerah. Sebut saja misalnya, untuk Sanoesi ia sering dipanggil ajengan Gunung Puyuh, atau untuk pimpinan Pesantren Sukamiskin Bandung disebut ajengan Sukamiskin, dan lain-lain (Iskandar, 2001: 11; Sulasman, 2007: 26).

${ }^{4}$ Sebelah Timur didirikan bangunan untuk pengajian masyarakat umum. Sebelah Selatan didirikan bangunan untuk belajar para santri (cikal-bakal madrasah Genteng). Sebelah Utara dibangun sebuah kolam (kulah) untuk mengambil air wudlu para santri dan jama'ah. Sebelah Barat adalah rumah Sanoesi dan keluarga (Falah, 2009: 31). 
Namun, ia mengaku tidak berani melakukan ijtihad, sebab hal tersebut tidak mudah. Dalam pendapatnya, sebuah kekeliruan apabila seseorang berijtihad dalam masalah agama selalu mendapat pahala meskipun pendapatnya salah. Berijtihad baru mendapat pahala apabila sebelumnya telah dipenuhi persyaratan untuk berijtihad. Oleh karena itu, Sanoesi sering mengatakan kepada para muridnya, bahwa dalam menjawab persoalan keagamaan harus didasarkan pada kitab-kitab kuning yang telah ditulis para ulama terdahulu (Sanoesi, 1930: 1).

Pada 1919 mulai terjadi polemik serius dalam masalah pemahaman keagamaan. Sanoesi menyerang ulama birokrat ${ }^{5}$ atau lebih dikenal ulama Kaum, karena tidak menjalankan hukum Islam secara konsisten dalam urusan zakan fitrah yang diserahkan kepada lebě (Penghulu desa), lalu diserahkan kepada Penghulu kecamatan dan dilanjutkan ke Penghulu kabupaten. Masing-masing Penghulu mendapatkan bagian yang telah ditentukan. Dalam fatwanya Sanoesi mengatakan, zakat fitrah ada ashnaf-nya (orang yang berhak menerimanya). Oleh karena itu, tidak boleh diserahkan kepada pihak yang bukan haknya. Pemerintah tidak boleh ikut campur untuk mengelola zakat fitrah. Zakat termasuk urusan agama. Undang-undang Raad Agama yang dikeluarkan oleh Sekretris Gubernur Jenderal tertanggal 1 Januari 1905, menyatakan, pemerintah Hindia Belanda netral agama (Sanoesi, tt.: 16). Fatwa Sanoesi tersebut segera diikuti oleh sejumlah ulama dan masyarakat di Sukabumi. Hal itu tentu mengundang kemarahan para Penghulu dan Bupati, karena pendapatan mereka berkurang (Iskandar, 1993: 27-28; Darmawan, 2009: 71).

Pada 1920, Sanoesi melakukan mujadalah (debat terbuka mengenai pemahaman keagamaan) dengan Oeyek Abdullah (imam mesjid Kaum Sukabumi). Debat itu dilaksanakan atas saran dan fasilitas hoofd Penghulu Sukabumi, Ahmad Djuwaini. Pada debat itu, semula akan dibahas mengenai tata kelola dan hukum zakat fitrah, namun kemudian dibatasi hanya terkait masalah slametan kematian. Dalam debat itu, Sanoesi berhasil mempertahankan pendapatnya dengan mendasarkan pada kitab Fath al-Mu'in dan 'Ianat al-Thalibin yang menyatakan slametan untuk orang yang sudah meninggal hukumnya haram (Sanoesi,1934: 1).

\footnotetext{
${ }^{5}$ Ulama birokrat dimaksud adalah ulama Kaum yang berpendirian tradisional dalam teologi dan fiqhnya. Mereka diangkat dan digaji oleh Pemerintah Hindia Belanda sebagai Penghulu atas usul Bupati atau Residen. Kebanyakan ulama Kaum adalah kerabat Bupati atau Residen, sehingga mereka sangat dekat secara kekeluargaan dengan pemerintah (Darmawan, 2009: 70; Lubis et al., 2009: 25).
} 
Pada 1925, polemik pemahaman keagamaan Sanoesi dengan ulama Kaum semakin terbuka. Polemik itu dipicu oleh fatwa Sanoesi tentang penghapusan doa bagi Bupati dan para pejabat yang diangkat pemerintah Hindia Belanda dalam teks khutbah Jum'at. Alasan Sanoesi, para pejabat tersebut bukan pemimpin kaum Muslimin. Polemik itu dikenal dengan sebutan abdaka maulana. Setelah itu tersebar isu, Sanoesi berani menghina Bupati Soeria Danoeningrat dengan sebutan Dalem Jendol, karena perutnya ngajendol (buncit), mardud, tukang ngigel, dan orang dholim (Sulasman, 2007: 35).

Selain berpolemik dengan ulama Kaum, Sanoesi juga berpolemik dengan kelompok mujadid (pembaharu). Dalam Silah al-Bashil fi al-Dharb 'Ala Tazahiq alBathil (1347: 1), Sanoesi menyebutkan, sejak 1924 hingga 1926 ia sering dikunjungi para propagandis gerakan modernis dari Garut dan daerah lainnya dan ditantang untuk diskusi terbuka. Di antara mereka adalah Muhammad Anwar Sanusi (Pesantren Biru), Muhammad Zakaria (Pesantren Cilame), Jusuf Taujiri (Pesantren Cipari, yang kemudian menjadi murid Sanoesi), dan Romli (Pesantren Haur Koneng) (Al-Hidajatoel Islamijjah, No. 1. Maret 1931; Lubis et al., 2009: 26). Selain itu dijumpai informasi, setelah Sanoesi menjadi Ketua Umum Al-Ittihadijatoel Islamijjah (AII) pernah melakukan debat dengan A. Hassan tokoh Persatuan Islam (Persis) dari Bandung (Wildan, 1995: 49). Masih dalam Silah al-Bashil (1347: 1), Sanoesi menyebutkan, setelah perdebatan itu para ulama yang mengatasnamakan kaum modernis tidak datang lagi ke Sukabumi. Baru setelah Sanoesi diinterneer di Batavia kelompok modernis itu datang kembali ke Sukabumi yang mengakibatkan kegamangan bagi para murid dan masyarakat Sukabumi.

\subsection{Sanoesi Menjadi Interneeran}

Pada 1926 pemerintah Hindia Belanda menangkap Sanoesi. Berdasarkan informasi Politieke Inlichtingen Dienst (PID), ia telah bersekongkol dengan kyai Samin untuk melakukan pemberontakan terhadap pemerintah Sukabumi. Tudingan itu dikaitkan dengan upaya sabotase pemutusan kabel telegraf kereta api yang dilakukan anak buah kyai Samin pada 1925 di kampung Babakan Sirna, Genteng (Mawardi, 2011: 102-103). Mula-mula Sanoesi ditahan selama dua tahun tanpa putusan pengadilan. Baru pada 1928 berdasarkan Besluit Gubernur Jenderal Hindia Belanda tanggal 11 September 1928, Sanoesi diasingkan ke Kampung Bali, Tanah Abang, Weltevreden, Batavia. Dalam besluit itu disebutkan alasan penangkapan bukan karena tuduhan bersekongkol dengan kyai Samin, tetapi lebih kepada aktivitas Sanoesi yang dipandang dapat membahayakan ketenangan dan ketertiban umum khususnya di Priangan Barat, karena murid dan 
pengikut Sanoesi semakin luas (Uitreksel uit het Register der Besluiten van den Gouverneur-Generaal van Nederlandsch-Indie No. 2 X, Batavia den 11den September 1928. ANRI).

Namun meskipun Sanoesi diasingkan, ia masih berhasil memelihara kontak dengan para murid dan pengikutnya. ${ }^{6}$ Terjalinnya kontak antara Sanoesi dengan para muridnya, dapat dipahami dari ajuan permohonan Sanoesi kepada Gubernur Jenderal ketika mengajukan permohonan izin pindah dari Gang Kampung Bali Kecil No. $6^{7}$ Tanah Abang, Batavia ke Gemeente Meester Cornelis, daerah Jatinegara sekarang (Surat Haji Ahmad Sanoesi, salinan dalam Mailrapporten. Geheim No. 1057 X /28. ARA). Surat permohonan Sanoesi disampaikan secara estapet ke Gubernur Jenderal, mulai dari Bupati, Komisaris Polisi, dan seterusnya. Selain itu, dalam menanggapi ajuan permohonan kepindahan Sanoesi di antara pejabat pemerintah Hindia Belanda tampak terjadi polemik. Misalnya, Bupati Batavia tidak merasa keberatan. Menurutnya apabila Sanoesi tetap tinggal di Batavia akan lebih membahayakan. Bupati mencium, bahwa Sanoesi sudah melakukan kontak dengan para propaganda PNI yang berpusat di Tanah Abang. Sementara Kepala Komisaris Polisi Batavia kurang setuju dengan pendapat Bupati. Menurutnya, sekarang saja dengan difungsikannya sistim pengawasan, Sanoesi masih dapat melakukan kontak dengan para kolega dan muridnya. Apalagi di Meester Cornelis yang belum ada pengawasan seperti di Batavia. Pendapat Kepala Komisaris Polisi mendapat dukungan dari Residen Batavia J.C. de Bergh. Bergh menambahkan, pemindahan Sanoesi ke Meester Cornelis sama saja dengan menumbuhkan persemaian baru disamping persemaian yang sudah ada di Tanah Abang. Nada yang sama disampaikan pula oleh Gubernur Jawa Barat (Iskandar, 1991: 247-248).

Pada waktu bersamaan, ketika para pejabat pemerintah Hindia Belanda sedang berpolemik antara menerima atau menolak ajuan permohonan kepindahan Sanoesi, Sanoesi sibuk menerima para kyai dan muridnya. Mereka menginformasikan sejumlah perkembangan pemahaman keagamaan di Keresidenan Priangan dan Buitenzorg,

\footnotetext{
${ }^{6}$ Sanoesi adalah kyai kharismatik. Meskipun ditahan di Batavia, kharismanya tidak pudar. Ia semakin banyak mendapat simpati masyarakat. Dalam surat Mantri Polisi tertanggal 21 Januari 1937, disebutkan, selama Sanoesi berada di Batavia tidak kurang dari 10.000 orang menjenguknya. Mereka tidak hanya datang dari Sukabumi, tetapi juga dari daerah lainnya. Kedatangan para pengikutnya disamping menjenguk, mereka juga membawa beberapa persoalan keagamaan (Sulasman, 2007: 67).

${ }^{7}$ Dalam surat permohonannya, Sanoesi menyebutkan alasan keinginan pindah dari Gang Kampung Bali ke Gemeente Meester Cornelis, karena di tempatnya itu sulit mencari penghidupan. Sementara tunjangan sejumlah $f 50$, dikatakannya tidak cukup untuk membiayai keluarganya (Iskandar, 1991: 246).
} 
khususnya di afdeeling Sukabumi (Iskandar, 1991: 251). Dalam kunjungannya, mereka membawa koran Sipatahoenan dan majalah Tjahaya Islam yang memuat tulisan kyai Ba'ali dan Anwar Sanusi tentang praktik ibadah. Dengan adanya tulisan mereka, masyarakat menjadi resah karena tidak tahu apakah ibadahnya sesuai syari'at Islam atau tidak (Sanoesi, 1930: 2; Iskandar, 1991: 252-253). Setelah membaca atikel yang dimuat pada koran dan majalah itu, Sanoesi menulis buku Tahdzirul Awam min Muftarayati Cahaya Islam. Buku itu terbit pada 1930 dan dicetak oleh Harun bin Ali Ibrahim Pekojan, Betawi (Sanoesi, 1930: 2).

Selain menulis Tahdzirul Awam min Muftarayati Cahaya Islam, sebagai kelanjutan dari kontak dengan sejumlah kyai dan para muridnya, Sanoesi kemudian menerbitkan majalah periodikal regular bulanan bernama Al-Hidajatoel Islamijjah (AHI) terbit perdana pada Maret 1931 (Al-Hidayatoel Islamijjah, No. 1. Maret 1931). Dengan diterbitkannya periodikal regular bulanan Al-Hidajatoel Islamijjah, pertemuan antara Sanoesi dengan para muridnya semakin intensif. Di sinilah Sanoesi mengusulkan perlunya dibentuk sebuah wadah yang dapat mempersatukan (al-Ittihad) kyai dan umat Islam di Sukabumi.

\section{Sanoesi sebagai Penggerak AII (1931-1945)}

Pada paroan akhir 1931 di afdeeling Sukabumi terdapat dua gerakan yang cukup berpengaruh, yaitu kaum mujadid (pembaharu) dan Partai Sarekat Islam (PSI). Atas dasar itu, pemerintah mengusulkan perlunya dibentuk organisasi tandingan. Gagasan tersebut disambut ulama Kaum (Iskandar, 1991: 254). Ulama Kaum yang diketuai Hasan Basri dari Pesantren Babakan Cicurug segera mengumpulkan para ulama Sukabumi untuk bergabung. Ia pun mengirim surat kepada Sanoesi di Batavia. Namun, Sanoesi yang sudah mengenal tabi'at Hasan Basri, menolak ajakan itu. Sehingga pertemuan ulama di Cicurug tanpa dihadiri Sanoesi (Sulasman, 2007: 69).

Mawardi (2011: 205) menyebutkan, setelah disepakati plat form organisasi, selanjutnya menentukan siapa yang akan menjadi ketua organisasi itu. Ulama Kaum menginginkan Hasan Basri yang kelak menjadi ketuanya, sementara para kyai di luar ulama Kaum, mengusulkan Sanoesi untuk menjadi ketuanya Kuat dugaan, karena ulama Kaum kalah jumlah, mereka mengalah asalkan tujuan yang ditugaskan pemerintah kepada mereka dapat terwujud. Oleh karena itu, mereka mengutus Dasuki ke Batavia untuk mengutarakan hasil pertemuan Cicurug sekaligus meminta Sanoesi untuk menjadi Ketua 
Umum organisasi itu. Setelah mendapat penjelasan dari Dasuki, Sanoesi bersedia menjadi vootzitter (ketua) organisasi tersebut (Sulasman, 2007: 70; Shaleh, 2011: 10-11).

Pada 21-22 November 1931 diadakan rapat perdana di Batavia Centrum. Dalam rapat itu, selain menetapkan nama organisasi Al-Ittihadijatoel Islamijjah (AII), menyusun pengurus Hoofdbestuur, juga menetapkan kantor pusat di Tanah Tinggi No. 191, KramatBatavia (Falah, 2009: 78). Adapun kegiatan utama AII adalah menyelenggarakan pengajian-pengajian, tabligh-tabligh, dan mendorong para kyai untuk mendirikan madrasah-madrasah.

Setelah menjadi Ketua Umum AII, pengaruh Sanoesi semakin kuat. AII meskipun secara formal merupakan organisasi sosial-keagamaan, namun dalam kenyataannya sering memasuki ranah pergerakan Nasional. AII dalam waktu singkat menjelma menjadi salah satu organisasi paling militan di wilayah Keresidenan Sukabumi dan Bogor (Iskandar, 1991: 256; Sulasman, 2007: 71). Hal tersebut dapat dipahami dari laporan Bupati Sukabumi tanggal 28 Agustus 1933, yang isinya menyatakan bahwa banyak di antara para kyai AII menjadi pemimpin-pemimpin Partij Indonesia (PI, Partindo) dan Partai Nasionalis Indonesia (PNI). Dalam laporan itu disebutkan pula, tidak sedikit di kalangan anggota PNI dan Partindo yang menjadi pengajar-pengajar di beberapa sekolah AII (Iskandar, 1991: 256; Sulasman, 2007: 71). Tampaknya kekhawatiran Bupati Sukabumi semakin kuat setelah membaca beberapa artikel yang dimuat dalam koran "Soeara Moeslim" yang menurutnya diterbitkan AII. Ia menyatakan, bahwa arah politik AII sangat jelas dan sangat aktif (Iskandar, 1991: 257).

Hingga 1933, status tahanan Sanoesi di Batavia Centrum belum jelas. Baru pada 3 Juli 1934, Gubernur Jenderal de Jonge menerbitkan besluit yang isinya Sanoesi dipindahkan ke Sukabumi dengan status sebagai tahanan kota (Besluit No. 32 tanggal 3 Juli 1934, koleksi Binnenlansche Bestuur No. 5154. ANRI; Iskandar, 1991: 259). Dengan terbitnya besluit tersebut, pada penghujung 1934, Sanoesi dan keluarganya kembali ke Sukabumi. Sehubungan status Sanoesi masih tahanan kota, ia tidak langsung pulang ke Pesantren Genteng atau ke Cantayan, karena keduanya berada di luar gemeente Sukabumi. Untuk itu Sanoesi menempati rumah di Cipelang Gede. Selanjutnya pindah ke rumah kakaknya (Abdoellah) di Vogelweg No. 100 (sekarang Jl. Bayangkara No. 33).

Kembalinya Sanoesi ke Sukabumi sangat membesarkan hati anggota AII sekaligus ancaman bagi kedudukan dan kewibawaan orang-orang non-AII. Ulama Kaum yang mendapat dukungan pemerintah terus berupaya membendung setiap aktivitas Sanoesi dan AII. Selain pemerintah, ulama Kaum juga mendapat dukungan dari Sarekat Hejo dan 
Pamitran. ${ }^{8}$ Aktivitas AII sering mendapat gangguan dari mereka. Atas gangguan itu, AII berkali-kali melaporkan kepada Assisten Wedana atau Bupati. Namun penangan mereka selalu lambat meskipun para korban mengenal betul para pelakunya. Menyadari perlindungan hukum yang tidak berpihak, anggota muda AII yang mayoritas terdiri dari para santri kemudian membentuk barisan pengawal yang diberi nama Barisan Ittihad Islamijjah (BII). Pada Kongres AII ke-II tahun 1937, BII secara resmi menjadi orgaan AII dengan Ketua Mh. Basjunie (Shaleh, 1966: 22-24; Sulasman, 2007: 73).

Pada penghujung 1938, diawali oleh terbitnya surat pernyataan Bupati Sukabumi Soeria Danoeningrat, jalan kebebasan Sanoesi mulai terbuka. Mantri Polisi Cianjur juga mengirimkan laporan kepada Residen Bogor pada 21 Januari 1939, bahwa di daerahnya terjadi aksi pengumpulan tanda tangan yang meminta agar Sanoesi segera dibebaskan. Laporan itu kemudian dijadikan pertimbangan Residen Bogor dalam suratnya kepada Gubernur Jawa Barat pada 25 Januari 1939. Oleh Gubernur Jawa Barat, pertimbanganpertimbangan itu disampaikan kepada Gubernur Jenderal. Pijper, Adviseur voor Inlandse Zaken, ikut menyetujui pernyataan Gubernur Jawa Barat (Iskandar, 1991: 273). Kebebasan Sanoesi akhirnya diperoleh pada 20 Februari 1939 setelah Gubernur Jenderal Tjarda van Starkenborgh mengeluarkan Surat Keputusan No. 3 yang berisi penyataan pembebasan Sanoesi dari segala hukuman (Iskandar, 1991: 274).

Pada 23-26 Desember 1939 AII melaksanakan Kongres ke-III di Bandung. Pelaksanaan Kongres ke-III AII berada dalam bayang-bayang perang Asia Timur Raya. Pada saat yang sama, di Hindia Belanda telah banyak berdiri partai atau organisasi yang berlandaskan agama (Islam) atau yang netral agama. Mereka mayoritas telah mengikatkan diri pada sebuah federasi. Hal itu menyebabkan beberapa anggota AII atau simpatisan menghendaki agar AII mendeklarasikan diri menjadi partai politik. Namun kongres menolak usulan itu. Alasannya, pertama, pada saat itu sudah terlalu banyak partai politik, termasuk partai Islam. AII tidak perlu membuat persaingan baru dengan partaipartai yang sudah ada. Di samping itu, dengan tanpa menjadi partai politik pun pada

${ }^{8}$ Menurut Iskandar (1991: 264), kelompok Sarekat Hejo dan Pamitran pada 1920-an terkenal di Priangan sebagai organisasi yang paling anti terhadap Sarekat Rakyat. Keduanya terus menebarkan ancaman tidak hanya saat pengajian AII berlangsung, tetapi di setiap ada kesempatan. Sebut saja misalnya, para santri kyai Nur dicegat dan dipukuli oleh anggota Sarekat Hejo di Selajambe Cisaat setelah mengikuti pengajian di tempat itu. Kasus lainnya terjadi di Soreang dan Cililin Bandung, anggota AII diserang orang-orang Pamitran. Tidak cukup di situ, mereka juga melakukan perusakkan terhadap rumah seorang ulama AII di Cililin (Al-Ittihadijatoel Islamijjah dalam Koleksi R.A. Kern No. 474. KITLV). 
kenyataannya sejumlah anggota AII telah mengambil bagian dari partai-partai. ${ }^{9}$ Kedua, sesuai statuten AII pasal 2, bahwa maksud perhimpunan adalah memadjoekan ketjerdasan dan perikehidoepan orang moeslimien Indonesia, anggota AII harus menghormati disiplin partai yang telah ada. AII tidak mengharapkan setiap anggotanya yang telah memasuki partai tertentu menjadi bingung akibat AII berubah menjadi partai politik. Dengan flat form yang sudah disusun dalam statuten, AII memberi kebebasan kepada para anggotanya dalam menyalurkan aspirasi politiknya kepada partai-partai yang sudah dipilihnya sendiri (Iskandar, 1991: 275; Mawardi, 2011: 208).

Pada Kongres ke-III, AII berhasil melakukan reorganisasi. Pada kongres itu terpilih sebagai Hoofdbestuur Abdoerrahim, salah seorang kader internal AII. Sementara Sanoesi mengisi posisi Adviseur (Penasihat) AII. Selain itu, sesuai dengan perkembangan kebutuhan organisasi, kongres memutuskan menambah lima buah Madjelis, yaitu: (1) Madjelis Tardjih, (2) Madjelis Tabligh dan Propaganda, (3) Madjelis Sosial, (4) Madjelis Ekonomi, dan (5) Madjelis Ittihadijjah Madaris Islamijjah (I.M.I). Selain itu, AII juga menetapkan dua organisasi otonom, yaitu Barisan Ittihad Islamijjah (BII) untuk pemuda, dan Zainabijah (barisan ibu-ibu dan pemudi) (Mawardi, 2011: 209).

Kongres ke-IV AII dilaksanakan pada 24-27 Desember 1940 di Cianjur. Peserta Kongres terdiri dari aggota AII, Zainabijah, Barisan Ittihad Islamijjah (BII), dan Ittihad Madaris Islamijjah (IMI). Pada saat itu, sejumlah partai pergerakan nasional sedang gencar menyuarakan Indonesia Berparlemen. AII pun menanggapi isu itu dengan penguatan badan otonom Barisan Ittihad Islamijjah (BII), dan Zainabijah. Kongres juga mengesahkan satu madjelis tambahan, Madjelis Pers (Wanta, 1991:19; Mawardi, 2011: 209).

Pada 24-27 Desember 1941, dilaksanakan Kongres AII ke-V di Batavia. Mawardi (2011: 210) menyebutkan, pada kongres itu lebih difokuskan pada penguatan orgaan AII. Hingga di sini, dari beberapa sumber yang ditemukan, hingga dilaksanakannya Kongres AII ke-V tidak ada satupun informasi yang menyebutkan pejabat pemerintah ikut menghadiri kegiatan itu. AII sengaja tidak mengundang pemerintah, karena Sanoesi dan anggota AII begitu antipati terhadap pemerintah Hindia Belanda (Darmawan, 2009: 66).

\footnotetext{
${ }^{9}$ Di antara anggota AII yang ketika itu menjadi anggota partai, sebut saja misalnya A. Zarkasji Sanoesi (Partai Islam Indonesia, PII), Atj. Mansur (Gerakan Indonesia, Gerindo), dan Mr. Samsuddin (Ketua Partai Indonesia Raya, Parindra Jawa Barat) (Shaleh, 1966: 24; Iskandar, 1991: 274).
} 
Sikap antipati Sanoesi dan anggota AII terhadap pemerintah Hindia Belanda berbanding terbalik dengan penerimaan mereka terhadap orang-orang Jepang. ${ }^{10}$ Informasi mengenai hubungan antara Sanoesi dengan pihak Jepang telah dimulai pada 1938 atau mungkin sebelumnya. ${ }^{11}$ Pada 1938 pemerintah Hindia Belanda sempat mencium hubungan itu. Namun Sanoesi berhasil meyakinkan, bahwa hubungan itu murni ekonomi untuk pemenuhan keperluan koperasi AII (Sulasman, 2007: 75; Darmawan, 2009: 67).

Dari hubungan itu, ${ }^{12}$ Sanoesi diduga memperoleh informasi mengenai kemungkinan akan masuknya tentara Jepang ke Hindia Belanda, disamping diterimanya dari teman-temannya di Madjelis Islam A'la Indonesia (MIAI) ${ }^{13}$ dan anggota AII yang aktif di partai politik. Selain itu, informasi mengenai kemungkinan akan masuknya tentara Jepang ke Hindia Belanda diperoleh Sanoesi dari beberapa diskusi dengan Sjahrir dan Hatta yang pada bulan-bulan pertama 1942 berada di rumah dinas Agent Polischeschool (sekolah Kepolisian, Secapa Sukabumi sekarang). Sjahrir dan Hatta diistirahatkan di Sukabumi setelah kembali dari pengasingannya di pulau Banda (Mawardi, 2011: 116).

Hingga di sini belum ditemukan informasi mengenai kapan masuknya Jepang ke Sukabumi. Namun, cepatnya proses pendudukan Jepang di Sukabumi, menurut Mawardi (1985: 98), tidak lepas dari peranan Sanoesi yang mengerahkan anggota AII dan BII untuk menunjukkan kantung-kantung pertahanan Belanda. Dengan pengalaman Sanoesi selama masa pemerintahan Hindia Belanda, pilihannya kepada pemerintah Pendudukan

\footnotetext{
${ }^{10}$ Mengenai asal-usul masuknya tentara Jepang ke Sukabumi belum ditemukan informasi yang memadai. Untuk kepentingan ini, peneliti mengikuti pendapat Notosusanto, (1984: 3), yang menyebutkan pada 5 Maret 1942 ibukota Batavia diumumkan sebagai "kota terbuka" yang tidak akan dipertahankan pemerintah Hindia Belanda. Setelah berhasil menguasai Batavia, tentara ekspedisi Jepang di bawah kepemimpinan Natsyu bergerak ke arah selatan dan berhasil menduduki Leuwiliang Buitenzorg. Melalui jalur inilah diduga Jepang masuk ke Sukabumi.

${ }^{11}$ Ketika terjadi depresi ekonomi di Hindia Belanda pada 1929, sejumlah produk murah dengan kualitas bagus dari Jepang membanjiri Hindia Belanda. Pada awal1930 orang-orang Jepang di Hindia Belanda telah banyak yang memiliki toko, studio foto, maupun tukang cukur. Di samping harga dan kualitas barang yang mereka tawarkan bagus, para pemilik tokonya dikenal baik dan ramah. Dari situ, diduga mulai munculnya simpati masyarakat Bumiputera kepada orangorang Jepang. Namun demikian, diinformasikan, di antara mereka banyak yang menjadi spionase (mata-mata) (Lubis, et. al., 2011: 166).

${ }^{12}$ Sanoesi memiliki hubungan baik dengan Muhammad Abdul Muni'am Inada (orang Jepang yang beragama Islam), karena Inada menjadi pemasok barang-barang keperluan koperasi AII. Belakangan diketahui, Inada merupakan pembantu Horie (pejabat yang menangani masalahmasalah keagamaan) (Poesponegoro dan Notosusanto, 1993: 23; Darmawan, 2011: 67).

${ }^{13}$ AII masuk menjadi anggota Madjelis Islam A'la Indonesia (MIAI) pada 1940. Sanoesi sebagai wakil dari AII tetap berada di organisasi itu meskipun berganti nama menjadi Madjelis Syoero Moelimien Indonesia (Masyumi) (Wanta, 1991: 22).
} 
Jepang bukan hanya sekedar kooperatif atau non-kooperatif, tetapi antara kompromi atau dihabisi. Dengan penuh kesadaran apabila bersikap non-kooperatif akan mendapat resiko yang lebih merugikan baik bagi dirinya maupun AII, Sanoesi kemudian menerima tawaran Muni'am Inada. ${ }^{14}$

Pada masa pemerintahan Pendudukan Jepang, kaum Muslim lebih memperoleh kelonggaran dibandingkan dengan masa pemerintahan Hindia Belanda (Benda, 1980: 165). Hal itu pula yang dirasakan Sanoesi. Bahkan dibanding dengan ulama lainnya, Sanoesi dan AII lebih banyak memperoleh kemudahan. Misalnya, pertama, ketika para ulama dan kaum Muslim lain diminta untuk tidak melakukan kegiatan-kegiatan yang bersifat politik, AII meskipun secara formal dibubarkan, namun dibiarkan melakukan kegiatan rutin, kecuali penerbitan (Mawardi, 2011: 117). Kedua, pada 19 Mei 1943 Sanoesi diangkat menjadi anggota Kaikyo Kyoshi Koshu-cho (intruktur pelatihan militer bagi para kyai). Masih pada tahun yang sama, Sanoesi berhasil melakukan negosiasi dengan pemerintah Pendudukan Jepang untuk menghidupkan kembali organisasi yang ia pimpin. Sebagai bukti keberhasilannya, pada September 1943 AII ${ }^{15}$ diperkenankan aktif. Ketiga, pada 25 Mei 1944, Sanoesi ditawari untuk menjadi anggota Dewan Penasihat Daerah (Shu Sangi Kai) Keresidenan Bogor. Pada tahun itu Sjamsoeddin, sebagai salah seorang anggota AII dan mantan aktivis Parindra yang dibubarkan pada 27 Juli 1942, ditawari menjadi ketua Gerakan Tiga A (Iskandar, 1991: 276; Sulasman, 2007: 76). Keempat, pada akhir 1944, Sanoesi diserahi jabatan sebagai Wakil Residen Bogor ${ }^{16}$ (Benda, 1980: 218). Kelima, ketika dibentuk Dokuritu Zyunbi Tyoosakai (Badan untuk Persiapan Kemerdekaan Indonesia) pada 29 April 1945, Sanoesi dan Sjamsoeddin masuk menjadi anggota Badan tersebut (Bahar et. al., 1995: xxv-xxvii; Lubis et al., 2011: 17).

Pernyataan penting Sanoesi dalam sidang-sidang BPUPKI terdapat pada sidang pleno 10 Juli 1945, ketika membahas bentuk negara kelak setelah Indonesia Merdeka. Saat itu Sanoesi dipersilakan mengemukakan pendapatnya oleh Radjiman. Inti usulan

\footnotetext{
${ }^{14}$ Sikap Sanoesi yang menerima tawaran kerjasama dengan pemerintah pendudukan Jepang, awalnya mendapat reaksi keras. Reaksi itu bukan hanya datang dari kalangan kyai non-AII, tetapi juga tokoh pergerakan Nasional, termasuk Soekarno (Iskandar, 1991: 276).

${ }^{15}$ AII diubah menjadi Persatoean Oemmat Islam Indonesia (POII) dan resmi berbadan hukum dari pemerintah Pendudukan Jepang pada 1 Februari 1944. POII pun mengalami perubahan ejaan Bahasa Indonesia pada 1947 (ejaan Soewandi) menjadi Persatuan Ummat Islam Indonesia (PUII) (Benda, 1980: 303; Iskandar, 1991: 276; Ambary, 2006: 253).

${ }^{16}$ Pada saat itu pemerintah Pendudukan Jepang mengadakan perubahan pejabat di lingkungan pemerintahannya. Sejumlah priyayi yang pada masa pemerintahan Hindia Belanda memiliki jabatan tinggi, hanya mengisi jabatan di tingkat daerah. Wakil dari kalangan Islam lainnya juga tidak ada yang mengisi jabatan setingkat Sanoesi. Sehingga Sanoesi merupakan satusatunya orang pribumi yang mengisi jabatan eksekutif (Sulasman, 2007: 77).
} 
Sanoesi bentuk negara Indonesia kelak adalah imamat (Iskandar, 1991: 277; Bahar et al., 1995:107-124). Selanjutnya Radjiman mengajukan stem (voting). Ketika akan dilakukan stem, Worjaningrat bertanya, "Lain-lainnya itu apa?" Jawab Radjiman, "misalnya hal imam, seperti yang diterangkan Toean Sanoesi tadi". Yamin kemudian menyatakan, "antara republik dan imamat tidak ada". Sanoesi kemudian menjelaskan, "maksud saya imam itu republik". Dari 64 stem, 55 memilih republik, 6 memilih kerajaan, 2 memilih lain-lain, 1 blanko (Bahar et al., 1995:124-125). Kiprah Sanoesi lainnya, ia mengusulkan perlunya batas wilayah bagi suatu negara merdeka (Bahar et al., 1995:157-158). Selanjutnya, ketika dibentuk panitia perancang Undang-Undang Dasar yang terdiri dari tiga Bunkakai (panitia), yaitu: (1) Bagian Undang-Undang Dasar, (2) Bagian Urusan Keuangan dan Perekonomian, dan (3) Bagian Pembelaan, Sanoesi masuk panitia Bagian Pembelaan (Bahar et al., 1995: 204).

\section{Peranan Sanoesi pada Awal Kemerdekaan Hingga Akhir Hayat (1945-1950)}

Setelah Indonesia Merdeka, sama halnya seperti Halim, aktivitas Sanoesi dan POII tidak lantas terhenti seiring berakhirnya masa pendudukan Jepang. Pada masa Perang kemerdekaan 1945-1949, Sanoesi tercatat sebagai anggota Komite Nasional Indonesia Pusat (KNIP). Ketika ditandatangani perjanjian Renville pada 1948 yang dalam salah satu butirnya dinyatakan bahwa ibu kota negara harus pindah dari Jakarta ke Yogyakarta dan Sukabumi bukan lagi bagian dari wilayah Indonesia, karena tugasnya itu Sanoesi harus hijrah meninggalkan Sukabumi ke Yogyakarta. Ketika berada di Yogyakarta, Abdoerrahim (ayah Sanoesi) wafat (Iskandar, 1991: 277-278; Mawardi, 2011: 121).

Keputusan politik Sanoesi yang tidak dapat diabaikan lainnya adalah penolakkannya terhadap Daarul Islam yang diproklamirkan Kartosoewirjo pada 1949. Ia kurang sepaham dengan ajaran Kartosoewirjo, karena dipandang banyak yang kurang sesuai dengan ajaran Islam yang ia pahami. Hal tersebut, misalnya keberadaan madjelis suffah dan adanya hak veto yang dipegang oleh sang imam (Jackson, 1990: 30-31; Sulasman, 2007: 103). Penolakan yang sama dilakukan pula oleh Yusuf Tojiri dari Cipari Garut, dan Badruddin dari Kadudampit Sukabumi beserta seluruh murid Sanoesi, Yusuf Tojiri, dan Badruddin (Iskandar, 1991: 278).

Setelah selesai Perang Kemerdekaan, Sanoesi pulang ke Sukabumi. Tampaknya, ia tidak mempunyai banyak waktu untuk membangun kembali pesantrennya, termasuk 
organisasinya. Ia wafat hari ahad malam, 15 Syawal 1369/1950 dalam usia 63 tahun. Ia dimakamkan ${ }^{17}$ di atas bukit sekitar 200 meter sebelah utara Pesantren Gunung Puyuh.

\section{PENUTUP}

Dari paparan di atas dapat dibuat simpulan, bahwa pergerakan Sanoesi telah dimulai sejak kepulangannya dari Mekkah. Ia menjadi Ajengan di Pesantren Cantayan. Melihat sambutan masyarakat terhadap keluasan ilmu Sanoesi, ayahnya menyarankan untuk membuka pesantren di Babakan Sirna Genteng. Setelah membuka Pesantren Genteng pengaruh Sanoesi semakin kuat. Dalam pengajiannya ia mulai berani mengeluarkan fatwa-fatwa yang menyebabkan ia berpolemik dengan ulama Kaum dan kaum Modernis. Kondisi tersebut membuat khawatir pemerintah Hindia Belanda. Oleh karena itu, salah satu cara yang ditempuh pemerintah adalah menangkap dan mengasingkan Sanoesi dari para murid dan koleganya. Sanoesi kemudian menjadi interneeran di Batavia Centrum.

Pengasingan Sanoesi ke Batavia Centrum tidak menyebabkan kontak dengan para murid dan koleganya putus. Justeru, di dalam pengasingan itulah Sanoesi didaulat oleh para murid dan koleganya untuk menjadi Hoofdbestuur Al-Ittihadijatoel Islamijjah (AII). Sebagai Ketua AII, karena sering mendapatkan perlakuan tidak adil, Sanoesi sangat antipati terhadap pemerintah Hindia Belanda. Hal sebaliknya ketika tentara pendudukan Jepang masuk ke Sukabumi. Dengan pertimbangan pengalaman pada masa pemerintah Hindia Belanda apabila melakukan konflik akan dihabisi, ia memilih kompromi. Pengalaman hubungan dagang dengan orang Jepang juga menyebabkan simpati Sanoesi terhadap pemerintah pendudukan Jepang. Pada masa pemerintah pendudukan Jepang Sanoesi dan anggota AII banyak memperoleh kemudahan. Di antaranya: menjadi Wakil Residen Bogor, anggota Cuo Sangi In, dan anggota Dokuritu Zyunbi Tyoosakai (BPUPKI).

\footnotetext{
${ }^{17}$ Mawardi, (1985: 55), menggambarkan prosesi solat jenazah dan pemakaman Sanoesi sebagai berikut:

“... tepi ka lima kali rintakan ngayakeun solat janazah di masjid, masih kurang keneh aya anu henteu kabagean ngama'mum, ... eta bae dibawa ti masjid ka pakuburan oge teu kungsi digotong, tapi ditatalepakeun. Mangkaning eta anu ngajajar di sisi jalan, bangunna teh kabeh oge pada hayang nyabak ..." (... hingga lima kali rombongan menyelenggarakan shalat jenazah di mesjid, namun masih terdapat orang yang tidak kebagian bermakmum, ... ketika dibawa dari mesjid ke pemakaman pun tanpa menggunakan keranda, tetapi cukup dengan dibopong secara bergiliran. Seluruh pelayat yang berdiri di sepanjang jalan menuju ke pemakaman semuanya ingin ikut ambil bagian dan menyentuhnya).
} 
Pergerakan Sanoesi tidak berhenti seiring berakhirnya masa pendudukan Jepang. Pada masa Perang kemerdekaan, Sanoesi tercatat sebagai anggota Komite Nasional Indonesia Pusat (KNIP). Ia pun ikut hijrah ke Yogyakarta. Hal terpenting lainnya, ia menolak keberadaan DI/TII di Jawa Barat.

\section{DAFTAR SUMBER}

\section{Arsip dan Dokumen Resmi Tercetak}

Al-Ittihadijatoel Islamijjah dalam Koleksi R.A. Kern No. 474. KITLV.

Besluit No. 32, tanggal 3 Juli 1934 dalam Koleksi Binnenlandsche Bestuur No. 5154. ANRI.

Gunseikanbu. 2602/1942.

Pendaftaran Orang Indonesia jang Terkemoeka jang Ada di Djawa, eks Arsip Gunseikanbu Cabang I, Pegangsaan Timur 36 Jakarta. Nomor S-283 gol. III b. Nomor berkas 547. ANRI.

Mailrapporten Geheim No. 953 geh/37. ARA.

Proces Verbaal Hadji Ahmad Sanoesi tanggal 7 Oktober 1919 dalam Koleksi R.A. Kern No. 278. KITLV.

Surat Residen Priangan tanggal 15 Desember 1927 No. 50/E dalam Mailr Geheim No. $679 \mathrm{X} / 28$. ARA.

Uitrekel uit het Register der Besluiten van den Gouverneur-Generaal van NederlandschIndie No. 2 X, Batavia den 11den September 1928. ANRI.

\section{Buku}

Ambary, Hasan Mu'arif. 2006.

"Sejarah Perkembangan Persatuan Ummat Islam (PUI)" dalam Revitalisasi Peran PUI dalam Pemberdayaan Ummat. Darun Setiady (ed.). Bandung: PW PUI Jawa Barat.

Bahar, Saafroedin et. al.1995.

Risalah Sidang Badan Penyelidik Usaha-Usaha Persiapan Kemerdekaan Indonesia (BPUPKI) Panitia Persiapan Kemerdekaan Indonesia (PPKI) $28 \mathrm{Mei}$ 1945-22 Agustus 1945. Jakarta: Setneg RI.

Benda, Harry J. 1980.

Bulan Sabit dan Matahari Terbit: Islam pada Masa Pendudukan Jepang. Terjemahan Daniel Dhakidae. Jakarta: Pustaka Jaya. 
Falah, Miftahul. 2009.

Riwayat Perjuangan K.H. Ahmad Sanusi. Sukabumi: MSI Cabang Jawa Barat bekerjasama dengan Pemerintah Kota Sukabumi.

Garaghan, Gilbert J. 1946.

A Guide to Historical Method. New York: Fordham University Press.

Gottschalk, Louis. 1975.

Mengerti Sejarah. Terjemahan Nugroho Notosusanto. Jakarta: Yayasan Penerbit Universitas Indonesia.

Jackson, Karl D. 1990. Kewibawaan Tradisional, Islam, dan Pemberontakan Kasus Darul Islam Jawa Barat. Terjemahan Pustaka Utama Grafiti. Jakarta: Grafiti.

Iskandar, Muhammad. 1993.

Kyai Haji Ajengan Ahmad Sanusi. Jakarta: PB PUI.

$-------, 2001$.

Para Pengemban Amanah Pergulatan Kyai dan Ulama di Jawa Barat 1900-1950. Yogyakarta: Mata Bangsa.

Lubis, Nina H. 2008.

Metode Sejarah. Bandung: Satya Historika.

et. al. 2009.

Sejarah Calon Pahlawan Nasional K.H. Ahmad Sanusi Berdasarkan Buku-buku dan Kesaksian Dalam Rangka Pengusulannya sebagai Pahlawan Nasional. Bandung: Dinas Sosial Propinsi Jawa Barat Bekerja sama dengan Pusat Kebudayaan Sunda Fakultas Sastra Unpad.

Poesponegoro, Marwati Djoened dan Nugroho Notosusanto. 1993. Sejarah Nasional Indonesia. Jilid VI. Jakarta: Balai Pustaka.

Renier, G.J. 1997.

Metode dan Manfaat Ilmu Sejarah. Terjemahan A. Muin Umar. Yogyakarta: Pustaka Pelajar.

Sanoesi, Ahmad. 1930.

Tahdzirul Awam min Muftarayati Cahaya Islam. Betawi: Sayyid Yahya bin Usman.

Tt.

Qawanin al-Diniyyat wa al-Dunyawiyyat fi 'Umur al-Zakat wa al-Fithrat. Sukabumi: Tp.

1934.

Al-Isyarat fi al-Farq bain Shadaqat wa al-Dhiyafat. Poncol Tanah Tinggi Batavia Centrum: Al-Ittihad.

1347. 
Silah al-Bashil fi al-Dharb 'Ala Tazahiq al-Bathil. Tanah Abang: Sayid Yahya bin Usman.

Shaleh, Anwar. 1966.

Sejarah Perjuangan Pemuda Persatuan Ummat Islam (PPUI). Bandung: Tp.

Shaleh, Munandi. 2011.

K.H. Ahmad Sanusi Pemikiran dan Perjuangannya dalam Pergolakan Nasional. Bekasi: Grafika Offset.

Sipahoetar, A.M. 1946.

Siapa? Lukisan tentang Pemimpin. Soekaboemi: Pertjetakan "Pemerintah". KITLV.

Sulasman. 2007.

K.H. Ahmad Sanusi 1889-1950: Berjuang dari Pesantren ke Parlemen. Bandung: PW PUI Jawa Barat.

Wanta, S. 1991.

KH Ahmad Sanusi dan Perjoangannya. Seri VII. Majalengka: PB PUI Majelis Penyiaran Penerangan dan Dakwah.

Wildan, Dadan. 1995. Sejarah Perjuangan Persis 1923-1983. Bandung: Gema Syahida.

\section{Tesis, Disertasi, Artikel/Entri dalam Majalah/Jurnal}

Al-Hidajatoel Islamijjah. No. 1. Maret 1931.

Darmawan, Dadang. 2009.

Ortodoksi Tafsir: Respons Ulama terhadap Tafsir Tamsjijjatoel-Moeslimien karya K.H. Ahmad Sanusi. Disertasi. Jakarta: UIN Syarif Hidayatullah.

Iskandar, Muhammad. 1991.

Para Pengemban Amanah Kyai dan Ulama dalam Perubahan Sosial dan Politik di Priangan c.a. 1900-1942. Tesis. Amsterdam: Vrije Universiteit. KITLV.

Mawardi, Asep Mukhtar. 1985.

Haji Ahmad Sanusi: Riwayat Hidup dan Perjuangannya. Skripsi. Jakarta: IAIN Syarif Hidayatullah.

------. 2011.

Haji Ahmad Sanusi dan Kiprahnya dalam Pergolakan Pemikiran Keislaman dan Pergerakan Kebangsaan di Sukabumi 1888-1950. Tesis. Semarang: Undip. 